\title{
The Influence of Policies on the Rural Part of the Pannonian Plain, Case Study: Region of Vojvodina
}

\author{
Tamara Lukić ${ }^{1}$, Bojan Đerčan ${ }^{1}$, Rastislav Stojsavljević ${ }^{1}$, \\ Milka Bubalo Živković ${ }^{1}$, Ivana Penjišević ${ }^{2}$, Tatjana Stojanović ${ }^{3}$ \\ ${ }^{1}$ Departmant of Geography, Tourism and Hotel Managemant, University of Novi Sad, Serbia \\ ${ }^{2}$ Faculty of Sciences, University of Priština, Kosovska Mitrovica, Serbia \\ 3 'Veljko Petrović' High School, Sombor, Serbia \\ Cooreponding author: snstamara@yahoo.com
}

Keywords: Pannonia countryside, policy, Province of Vojvodina, farmers

\begin{abstract}
In this article are given the opinions by Pannonia countryside inhabitants that belong to the Republic of Serbia about some characteristics of everyday policy. The opinions are gathered by poll which was distributed by e-mail to different areas of the Province of Vojvodina. Namely, 122 participants who filled the poll correctly estimated ten stances. They were formed on the basis of the themes about which the farmers have most often discussed. Special attention was directed to differences concerning the opinion of participants of different gender and age structure, activity and political engagement. Descriptive statistics, T-test and one-factor analysis of ANOVA variance have been used for establishing the differences and were complemented by Post-hoc Tukey test. This paper could be used for improvement of connections and relationships among the politicians, policy and countryside.
\end{abstract}

\section{INTRODUCTION}

The idea about the article theme is a result of perception made during one fieldwork investigation. Namely, it was noticed that everyday policy attracted the attention of man who lives in rural environment. Most often was discussed about manners of government members, local authorities and other politicians, about women in policy, elections and changes brought by them. Visibly is that many people think that they know very well the situation in policy and how different questions should be treated. Ten stances were formed accordingly. On this topic, scientists have never been directly devoted attention, but similar ideas can be directly or indirectly identified in various research papers made by Akram-Lodhi \& Kay (2012); Blunden \& Curry (1988); Braton (1990); Dwyer (2011); Scott et al. (2011); Shortall (2012) and Winter (2013). In 2013, Lukić et al. (2014) conducted similar surveys in southern Serbia. This area is inhabited by a majority Serbian population. Compared with the region of Vojvodina, southern Serbia has different geographical circumstances and different historical and cultural heritage.

Investigation was conducted in the area of the north part of the Republic of Serbia which belongs to the Pannonia plain, geographical observed. Lowland relief, adequate moderate continental climate, underground and surface water resources and fertile land had always drew the inhabitants toward this part of Pannonia plain (Gaćeša, 1972; 1975; Janjetović, 2012; Ljubojević, 2012; Ramač, 2012) and influenced so that there were a high degree of population density and a great number of villages. In the $21^{\text {st }}$ century those villages have a high degree of urbanization. Modern technologies (television, mobile phones, Internet) have become completely accessible and in that way made possible undisturbed flow of information. The aim of this article is to establish how established stances were exact, respectively, how much a man who lives in rural environment of Vojvodina was 'touched' by everyday policy; how much he was informed about it and its protagonists as well as what his attitudes are about certain questions. The themes are interesting because they point to some society phenomena regardless of which political party is in power. 


\section{METHODS}

The research was conducted within the poll in following municipalities: Bačka Palanka, (villages: Silbaš, Karađorđevo and Despotovo), Irig (village: Neradin), Ruma (village Hrtkovci), Sremska Mitrovica (villages: Šuljam and Bešenovo), Kovin (village: Bavanište), Šid (villages: (Vašica, Adaševci, Berkasovo, Erdevik, Bingula and Morović), Bačka Topola (villages: Svetićevo and Pobeda), Zrenjanin (village: Lazarevo), Sečanj (villages: Jaša Tomić and Sečanj) (Figure 1). An attempt was made to participants in the study inhabit areas that are not close to cities.

Of the total number of adult inhabitants of Vojvodina, 645103 or $49.6 \%$ not living in cities (RZS, 2014). In accordance with the simple Size Calculator, on the confidence-level of $90 \%$, the minimum recommended sample size is 271 (Raosoft, 2014). From 275 participants, the poll correctly filled 122 or $44.4 \%$. Those were mostly the female persons (55.7\%). Some authors believe that the estimations from applied statistics methods will be good only if the sample contains minimum 51 units (Bagozzi, 1981; Iacobucci, 2010). Factor analysis should not be done with less than 100 observations (Bartlett et al, 2001). Actually, an effort should be made to get the sample of more than 100 examinees (Bagozzi \& Yi, 2012). Taking into consideration above stated it may be concluded that the sample used in this investigation $(n=122)$ is representative.

From total number of participants $3 / 4$ have not been politically engaged, $1 / 3$ was employed while the agricultural made $18.0 \%$. Starting from the idea that 'the world remains on younger's' almost the third of participants belongs to the age category between 20-29 years (Table 1).

\begin{tabular}{llll}
\multicolumn{4}{l}{ Table 1 Sample of respondents 122, Source: Survey research and own calculations } \\
\hline Gender & In\% & Membership of the political option & In \% \\
& & & 22.1 \\
\hline Male & 44.3 & Correct & 77.9 \\
Female & 55.7 & Incorrect & In \% \\
\hline Age & In \% & Activity & 18.0 \\
\hline $20-29$ & 32.8 & Farmer & 5.7 \\
$30-39$ & 19.7 & Farmer with employed & 33.6 \\
$40-49$ & 13.1 & Employed & 9.0 \\
$50-59$ & 17.2 & Pensioner & 14.8 \\
$60+$ & 17.2 & Unemployed & 18.9 \\
& & Other &
\end{tabular}




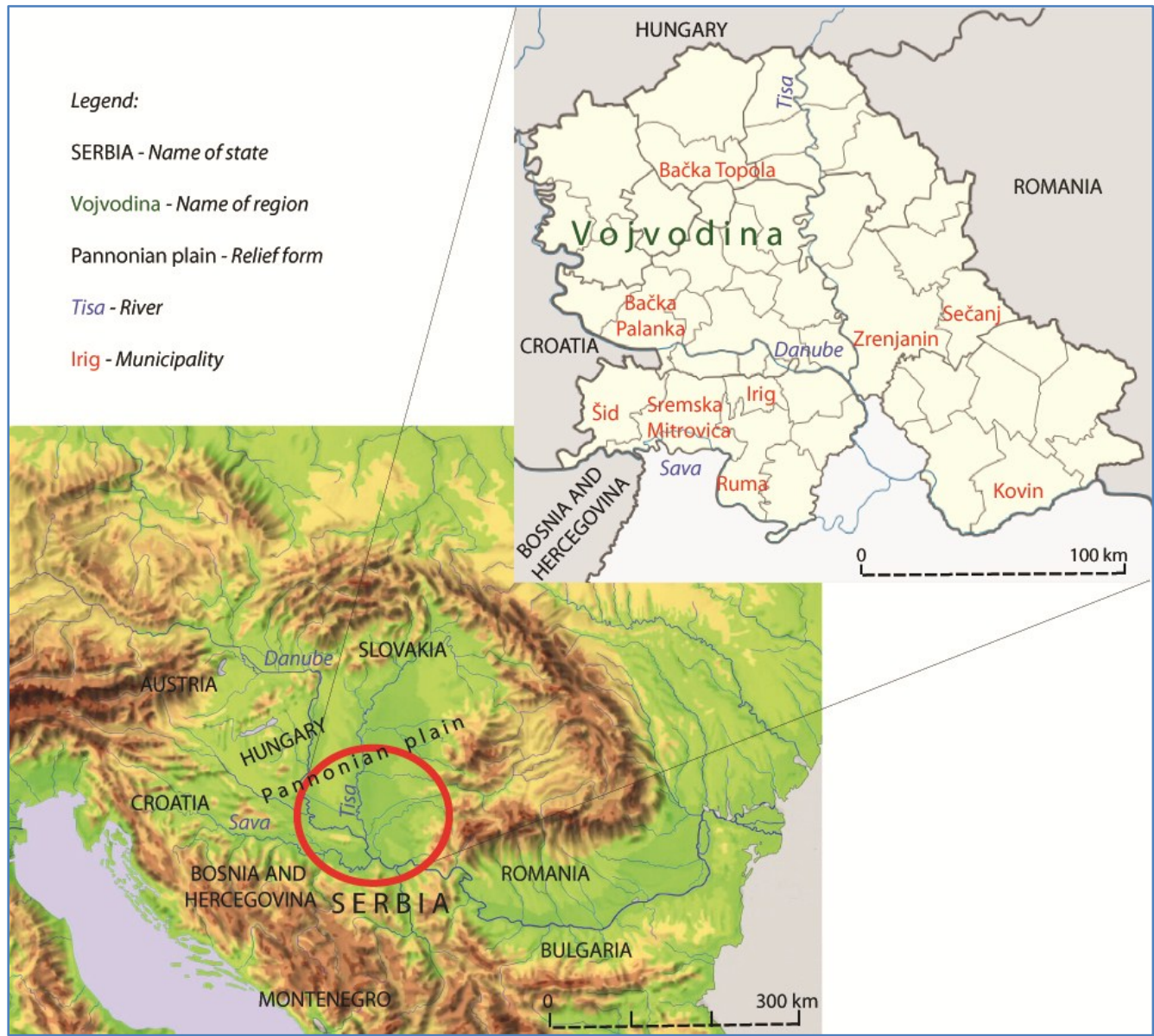

Figure 1 Geographic position of municipalities where are the settlements in which the participants live, Source: Zentai, 1996; Map 1, 2014

Survey stances were measured on a five-point Likert type scale ranging from 1 (strongly disagree) to 5 (strongly agree). The interwieving was conducted during the summer and autumn 2013. Data were analyzed by descriptive statistics and using T-test, one-factor analysis of ANOVA variance and Post-hoc Tukey HSD test. T-test was made with independant samples and compared by arithmetic mean of two groups. As it was not possible to assume the result of comparation, 2 tailed test was used. The results of T-test discovered significant statistic differences between average mean of the participants gender, political engagement and the origin of the participants according to the altitude they have settled, at the importance level $p<0.01 \quad(t \geq 2.57)$ (Pearson \& Hartley, 1966).

\section{RESULTS AND DISSCUSIONS}

Descriptive statistics of established survey stances shows that the examinees declared positively in four, indecisive in five and disagreement has been shown only in one of ten established survey stances. There was no absolute mutual agreement of ten hypotheses among the participants, respectively; standard deviation value was shown everywhere more than 1 . The most degree of mutual agreement, respectively value of standard deviation has been a little bit over $1(\sigma=1.02)$, established in stance 'If I were the politician I would know what should be changed' (Figure 2). The most mutual disagreement refers to the opinion about presence of politicians in rural environment during the political campaign $(\sigma=1.30)$.

Stance one: 'I regularly follow 'the political life' in Vojvodina'. The participants could not definitely confirm that they regularly follow 'the political life' in Serbia $(M=3.05)$ and the reply was quite different $(\sigma=1.22)$ (Figure 2). The Province of Vojvodina has well organized political life and authority organs in different levels. Some of the participants made comments that their political interest was focused on political happenings on the Provincial level, than the state level. T-test has 
shown differences on the significance level from $\mathrm{p}<0.01$ between the genders and political activity (Table 2). Men said that they regularly follow 'the political life' in comparison to women. The political activists, naturally, agreed that they regularly follow the 'political life' $(\mathrm{M}=3.96)$. Those who were not politically active were unable to show their agreement $(M=2.79)$. One-factory analysis of ANOVA variance, at the importance level $\mathrm{p}<0.01 ; \mathrm{F} \geq 3.47$ has shown difference in opinion of participants between different age groups, but it has not found significant differences among the opinions of participants with different occupations. Post hoc Tukey test has shown that the greatest difference in opinion was between the participants who belong to the oldest category $(60+)$ and those in category age 30-39. The examinees older than 50 years agree with stance that they regularly follow 'the political life', while participants in younger age groups were indecisive. Older participants were mutually more agreeable concerning their replies in comparison with younger ones (Table 5). Research by Haerpfer et al. (2002) has found that in the East European countries generally was present a great level of alienation from the policy by young people. Wallace (2003) drew attention on increasing level of apathy by young people concerning the policy. Čičkarić (2007) has noticed that after regime was changed in the year 2000 in Serbia started certain processes that have already been established in developed societies, according which individualization and privatization made weaken the motivation of young people to participate in policy. McDonald Ladd and Lenz (2011) have noticed that the citizens do not pay much attention toward the policy.

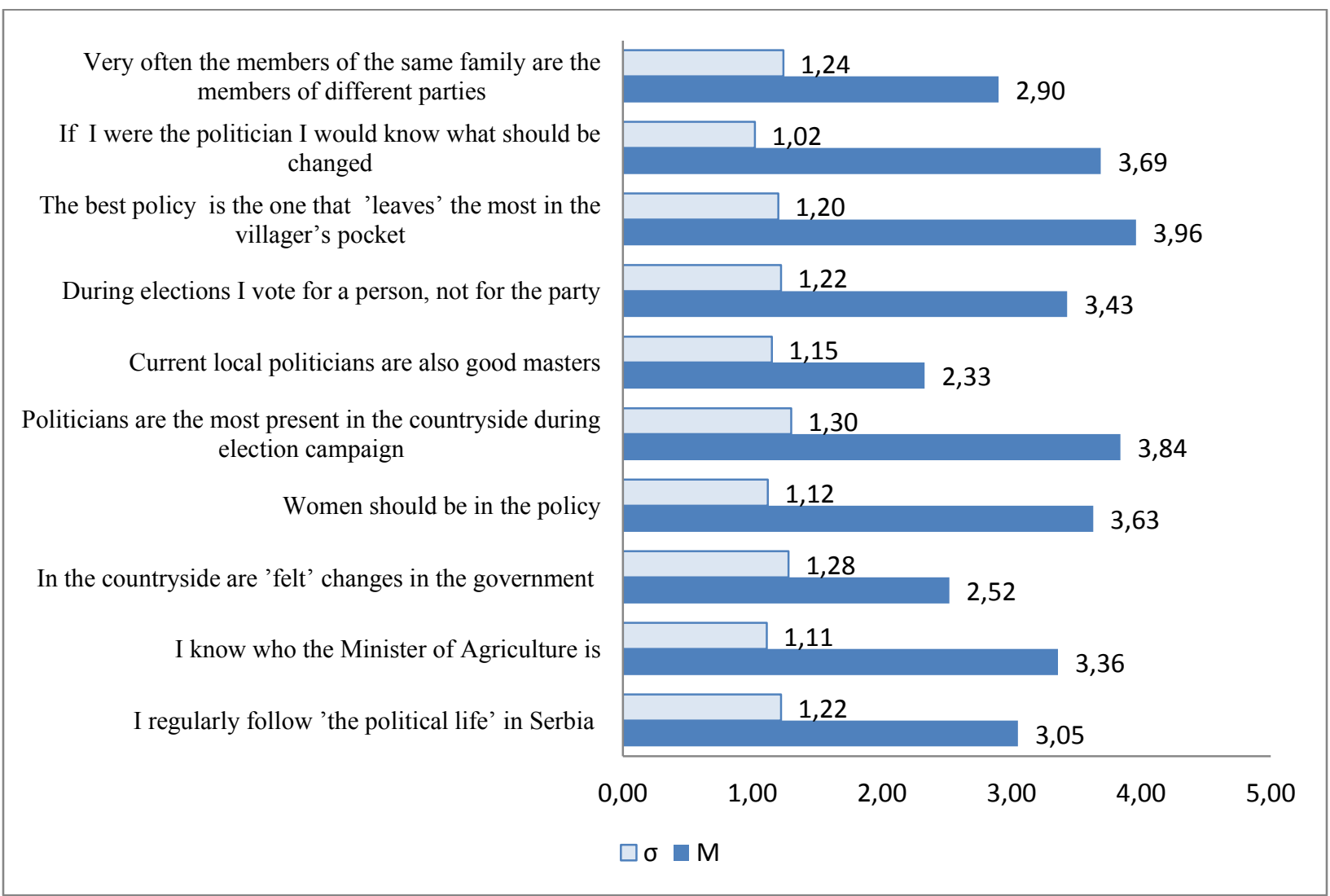

Figure 2 Descriptive statistics for individual stances (M-average value, $\sigma$-standard deviation) Source: Survey research

Stance two: 'I know who the Minister of Agriculture is'. The inhabitants of countryside have direct or indirect connections with agricultural activity. Naturally, a decision by the Minister of Agriculture should be the subject of farmers' discussion. During preliminary terrain observations was noticed that in the countryside were discussions about the Minister, but it was not quite clear the proportion of basic characteristics of conducted policy. There are certain problems in agriculture such as price disparity, financing, the fall of agrarian products export, cattle breeding crisis, are altogether present (Pejanović \& Tica, 2001) and prevails the opinion that the Minister is responsible 
for such existence, whoever he may be. The poll has shown that the participants were not sure who the Minister of Agriculture was $(\mathrm{M}=3.36)$. They mutually are more agreeable about this question in comparison with the other stances $(\sigma=1.11)$ (Figure 2). During research the government of the Republic of Serbia was in the process of reconstruction. Most people knew the former Minister as he had other media exposed functions before he came on this duty. Up to that moment, newly appointed Minister has not be known in large-scale of public. T-test has not shown statistically significant differences on the level of $p<0.01$. According to the average value, men and politically engaged participants agreed that it was known to them who the Minister of Agriculture was, while the others did not know. One-factory analysis of ANOVA variance, at the importance level $p<0.01$; $\mathrm{F} \geq 3.47$, has not been shown among the participants. Descriptive statistics of the analyzed population categories were selected respondents 55-59 years and farmers, as the only ones who have confirmed that they know who the Minister of agriculture is, while others could not say. This stance illustrates, among the others, how much certain Government is involved in its publicity (Robson, 1940) and how much it works in the field of expanding the information about promoted policy.

Stance three: 'In the countryside are 'felt' changes in the government'. The world examples show that the policy has influenced on changes in the countryside life (Bratton, 1990; Dwyer, 2011; Winter, 2013), but if there was no clear 'rural vision', they were missing (Scott et al, 2011). It was obvious that in Britain were looking at policy ideas, concepts and compatibilities, as well as making assessments of their impact and examining exactly how they might be implemented and allocated resources in practice (Blunden \& Nigel, 1988). Society democratization at the end of the $20^{\text {th }}$ century (Spasić \& Petrović, 2012) brought the possibility for change of the authorities and within it, different political understanding and visions. It might be said that almost all political options so far came to power. Stance was formed in order to investigate whether the changes in political sphere changed the situation in village. The participants could not say 'if in the countryside are 'felt' changes in the government' $(\mathrm{M}=2.52, \sigma=1.28$ ) (Figure 2). Neither T-test nor ANOVA found statistically significant changes between different categories of participants. Received values by descriptive statistics has shown that with this stance do not agree: women, those politically not engaged, older than fifty years, farmers, nevertheless, if they work or they were only in agriculture and other (category where it was the most important part an example of housewives). So, in Vojvodina countryside were not felt changes by those who in the economic sense mostly depend from agriculture.

Stance four: 'Women should deal with the policy'. Interlocutors who motivated the forming of such hypothesis did not have high opinion about women in policy. They referred to accepting stereotype based and traditional views of women role in society about which also spoke Viđen (2010). Phenomenon of gender equality in policy had been mentioned very often (Čičkarić, 2005; Kamenov et al, 2010; Gardiner, 2013; Krook \& Norris, 2014). However, participants who accepted to participate in this investigation has shown their agreement with this stance $(M=3.63)$ (Figure 2). T-test has shown that according to gender criteria there are significant statistical differences $(p<0.01)$. Women agree with this stance, while men are indecisively concerning this question (Table 2). Differences according to criteria of policy engagement are not so significant for this stance. Politically engaged participants has shown larger agreement $(\mathrm{M}=4.00)$ in comparison to the others $(\mathrm{M}=3.53)$. One-factory analysis of ANOVA variance, at the importance level $\mathrm{p}<0.01$; $\mathrm{F} \geq 3.47$, has not shown the statistically significant differences between the participants. According to the age of participants, the highest level of agreement was shown by the youngest participants, 'those to whom the world belongs to'. Among the participants groups classified according to their activities, only the farmers remained indecisive $(\mathrm{M}=3.36)$ while the others more or less agreed. Pološki Vokić and Bulat (2013) pointed out that necessity for satisfying the needs of different groups in society, solving of different problems faced by the society as well as broad and creative activities, were possible only if the problematic areas and questions have envisaged the problem in different angles, but it was brought in this policy by women. 
Table 2 Differences concerning the inhabitants of rural settlements in Vojvodina on the basis of gender (M-average value, $\sigma$ - standard deviation, $t$-value, $\mathrm{p}$-importance level $(\mathrm{p}<0.01))$, Source: Survey research and own calculations

\begin{tabular}{llllll}
\hline Stances & Gender & $\mathrm{M}$ & $\sigma$ & $\mathrm{t}(122)$ & $\mathrm{p}$ \\
\hline I regularly follow 'the political life' in Serbia & Male & 3.463 & 1.209 & 2.965 & $\mathbf{0 . 0 0 4}$ \\
& Female & 2.721 & 1.131 & \\
& Male & 3.500 & 1.145 & 1.376 & 0.172 \\
I know who the Minister of Agriculture is & Female & 3.250 & 1.084 & & \\
& Male & 2.667 & 1.346 & 1.103 & 0.272 \\
In the countryside are 'felt' changes in the government & Female & 2.397 & 1.223 & \\
& Male & 3.278 & 1.140 & 3.142 & $\mathbf{0 . 0 0 2}$ \\
Women should be in the policy & Female & 3.912 & 1.033 & \\
Politicians are the most present in the countryside during & Male & 3.981 & 1.394 & 1.299 & 0.196 \\
election campaign & Female & 3.735 & 1.217 & \\
Current local politicians are also good masters & Male & 2.315 & 1.271 & 0.304 & 0.761 \\
& Female & 2.338 & 1.045 & \\
During elections I vote for a person, not for the party & Male & 3.333 & 1.274 & 0.423 & 0.673 \\
The best policy is the one that 'leaves' the most in the & Female & 3.500 & 1.178 & \\
villager's pocket & Fale & 4.056 & 1.366 & 8.431 & 1.000 \\
If I were the politician I would know what should be & Male & 3.882 & 1.044 & \\
changed & Female & 3.500 & 1.025 & 2.062 & 0.041 \\
Very often the members of the same family are the members & Male & 3.074 & 1.286 & & \\
of different parties & Female & 2.765 & 1.186 & 1.867 & 0.064 \\
\hline
\end{tabular}

Stance five: 'Politicians are the most present in the countryside during the election campaign.' Population of villages in Vojvodina need to solve certain problems concerning the life quality. Their opinion is that the representatives of the Parliament of Serbia may help them. However, at the Parliament of Serbia, for example, after the elections in the year 2008, the number of members of Parliament have been dominant from Belgrade and Novi Sad, while the great number of units of local self-management 98 (from totally 150 communities, 23 cities, and the capital Belgrade) had no representatives of local self-management in the Parliament (Orlović, 2010). This problem was noticed out of Serbia, also (Shortall, 2012). According to this, it is understandably that interlocutors criticized the politicians as they could see them only during the elections. This stance is one of those where the most participants agreed with $(\mathrm{M}=3.84, \sigma=1.30)$. Concerning this question the world experience was that there had not been any campaign character of approach to the voters in comparison to those in Serbia (Anojčić, 2008). Standard deviation was the biggest one in comparison to the other stances which shows that there was a smaller group of participants who did not agree. T-test has not shown statistically significant data between genders of participants but they were identified on the level of significance from $p<0.01$ among the participants who were politically active and the others (Table 3 ). Neither the age criteria nor the activity criteria, one-factory analysis of ANOVA variance, at the importance level $\mathrm{p}<0.01 ; \mathrm{F} \geq 3.47$ ) has not shown significant statistic difference among the participants. In both case more groups agreed with stance. Indecisive were pensioners and participants of the age group 30-39. Life monitoring in the countryside was desirable and real within a good organization which was shown by number of examples (O'Brien, 1994; Dramstad et al, 2002) and populous and wider countries than it is Serbia. 
Table 3 Differences concerning the inhabitants of rural settlements in Vojvodina according to the political engagement $(\mathrm{M}-$ average value, $\sigma-$ standard deviation, $\mathrm{T}$-value, $\mathrm{p}$-importance level $(\mathrm{p}<0.01))$. Source: Survey research and own calculations

\begin{tabular}{|c|c|c|c|c|c|}
\hline Stances & $\begin{array}{l}\text { Political } \\
\text { engagement }\end{array}$ & M & $\sigma$ & $\mathrm{t}(122)$ & $\mathrm{p}$ \\
\hline \multirow{2}{*}{ I regularly follow 'the political life' in Serbia } & Correct & 3.963 & 1.055 & \multirow{2}{*}{3.461} & \multirow{2}{*}{0.001} \\
\hline & Incorrect & 2.789 & 1.138 & & \\
\hline \multirow{2}{*}{ I know who the Minister of Agriculture is } & Correct & 3.778 & 0.974 & \multirow{2}{*}{2.292} & \multirow{2}{*}{0.024} \\
\hline & Incorrect & 3.242 & 1.127 & & \\
\hline \multirow{2}{*}{$\begin{array}{l}\text { In the countryside are 'felt' changes in the } \\
\text { government }\end{array}$} & Correct & 2.852 & 1.406 & \multirow{2}{*}{1.482} & \multirow{2}{*}{0.141} \\
\hline & Incorrect & 2.421 & 1.234 & & \\
\hline \multirow{2}{*}{ Women should be in the policy } & Correct & 4.000 & 0.961 & \multirow{2}{*}{2.254} & \multirow{2}{*}{0.026} \\
\hline & Incorrect & 3.526 & 1.147 & & \\
\hline \multirow{2}{*}{$\begin{array}{l}\text { Politicians are the most present in the } \\
\text { countryside during election campaign }\end{array}$} & Correct & 4.111 & 1.219 & \multirow{2}{*}{2.546} & \multirow{2}{*}{0.012} \\
\hline & Incorrect & 3.768 & 1.316 & & \\
\hline \multirow{2}{*}{ Current local politicians are also good masters } & Correct & 2.222 & 1.281 & \multirow{2}{*}{0.208} & \multirow{2}{*}{0.836} \\
\hline & Incorrect & 2.358 & 1.110 & & \\
\hline \multirow{2}{*}{$\begin{array}{l}\text { During elections I vote for a person, not for } \\
\text { the party }\end{array}$} & Correct & 3.074 & 1.466 & \multirow{2}{*}{2.004} & \multirow{2}{*}{0.047} \\
\hline & Incorrect & 3.526 & 1.128 & & \\
\hline \multirow{2}{*}{$\begin{array}{l}\text { The best policy is the one that 'leaves' the } \\
\text { most in the villager's pocket }\end{array}$} & Correct & 4.407 & 0.971 & \multirow{2}{*}{2.087} & \multirow{2}{*}{0.039} \\
\hline & Incorrect & 3.832 & 1.226 & & \\
\hline \multirow{2}{*}{$\begin{array}{l}\text { If I were the politician I would know what } \\
\text { should be changed }\end{array}$} & Correct & 4.185 & 0.879 & \multirow{2}{*}{3.058} & \multirow{2}{*}{0.003} \\
\hline & Incorrect & 3.547 & 1.019 & & \\
\hline \multirow{2}{*}{$\begin{array}{l}\text { Very often the members of the same family } \\
\text { are the members of different parties }\end{array}$} & Correct & 2.741 & 1.347 & \multirow{2}{*}{0.369} & \multirow{2}{*}{0.713} \\
\hline & Incorrect & 2.947 & 1.206 & & \\
\hline
\end{tabular}

Stance six: 'Current local politicians are also good masters'. There are negative prejudices about ability and morality of politicians (Ramet, 2005; Đinđić, 2013). 'Recruitment of prominent hosts' or 'political activity' of rich farmers was desirable political act. So-called 'prominent hosts' are those who succeeded in their work and it was expected that positive changes would happen by their participation in the policy. All problems are known to a native man and he faced them, and 'he has shown how they may be solved in the best way'. How difficult is to agree with some 'good' master to be politically active? What is his interest, if he has already realized and proved himself (Jamieson, 2010). Obviously if they were a lot of them in the policy; this would not be rejected stance. The participants did not agree that current local politicians are also good masters $(\mathrm{M}=2.33)$, but this is a rare one about which they almost mutually agreed $(\sigma=1.15)$ (Figure 2). T-test did not show statistically significant differences between genders, nor between those who were politically engaged and those who were not. Supposing that the politically engaged participants are more informed about their colleagues who hold power then their non-agreement $(\mathrm{M}=2.22)$ was a proof that good and successful hosts are not engaged in policy but certain form of confirmation that being in policy might be the alternative aspect of self-employment. According to the age criteria, onefactory analysis of ANOVA variance, at the importance level $p<0.05 ; \mathrm{F} \geq 2.44$, has found that the youngest (20-29) polled category, in contrast to the others, do not deny this stance, but it is indecisive $(\mathrm{M}=2.60, \sigma=0.87)$. Their indecisive may be a result of being uninformed as they were indifferent. According to the activity category, unemployed were separated as the only one indecisive $(\mathrm{M}=2.67)$ while the other categories of participants rejected this stance. 
Table 4 One-factor analysis of differences between the inhabitants of rural settlements of Vojvodina based on the years of participants (M-average value, $\sigma$-standard deviation, for $\mathrm{F}(4,117)$, critic values according to Snedecor \& Cochran table (1980), $\mathrm{p}<0.01 ; \mathrm{F} \geq 3.47 ; \mathrm{p}<0.05 ; \mathrm{F} \geq 2.44$ ). Source: Survey research and own calculations

\begin{tabular}{|c|c|c|c|c|c|}
\hline Stances & Years & M & $\sigma$ & $\mathrm{F}$ & $\mathrm{p}$ \\
\hline \multirow{5}{*}{$\begin{array}{l}\text { I regularly follow 'the political life' in } \\
\text { Serbia }\end{array}$} & $20-29$ & 2.775 & 1.250 & \multirow{5}{*}{4.7753} & \multirow{5}{*}{0.0013} \\
\hline & $30-39$ & 2.583 & 1.248 & & \\
\hline & $40-49$ & 2.812 & 0.981 & & \\
\hline & $50-59$ & 3.619 & 1.024 & & \\
\hline & $60+$ & 3.714 & 1.056 & & \\
\hline \multirow{5}{*}{ I know who the Minister of Agriculture is } & $20-29$ & 3.350 & 1.312 & \multirow{5}{*}{0.3091} & \multirow{5}{*}{0.8714} \\
\hline & $30-39$ & 3.167 & 1.204 & & \\
\hline & $40-49$ & 3.438 & 0.964 & & \\
\hline & $50-59$ & 3.524 & 1.030 & & \\
\hline & $60+$ & 3.381 & 0.805 & & \\
\hline \multirow{5}{*}{$\begin{array}{l}\text { In the countryside are 'felt' changes in the } \\
\text { government }\end{array}$} & $20-29$ & 2.675 & 1.185 & \multirow{5}{*}{1.4297} & \multirow{5}{*}{0.2285} \\
\hline & $30-39$ & 2.708 & 1.301 & & \\
\hline & $40-49$ & 2.812 & 1.424 & & \\
\hline & $50-59$ & 2.095 & 1.300 & & \\
\hline & $60+$ & 2.190 & 1.250 & & \\
\hline \multirow{5}{*}{ Women should be in the policy } & $20-29$ & 3.925 & 1.095 & \multirow{5}{*}{1.3078} & \multirow{5}{*}{0.2712} \\
\hline & $30-39$ & 3.417 & 1.213 & & \\
\hline & $40-49$ & 3.562 & 0.892 & & \\
\hline & $50-59$ & 3.667 & 1.238 & & \\
\hline & $60+$ & 3.333 & 1.065 & & \\
\hline \multirow{5}{*}{$\begin{array}{l}\text { Politicians are the most present in the } \\
\text { countryside during election campaign }\end{array}$} & $20-29$ & 4.075 & 1.141 & \multirow{5}{*}{1.8646} & \multirow{5}{*}{0.1213} \\
\hline & $30-39$ & 3.375 & 1.377 & & \\
\hline & $40-49$ & 3.938 & 1.340 & & \\
\hline & $50-59$ & 4.190 & 1.209 & & \\
\hline & $60+$ & 3.524 & 1.436 & & \\
\hline \multirow{5}{*}{$\begin{array}{l}\text { Current local politicians are also good } \\
\text { masters }\end{array}$} & $20-29$ & 2.600 & 0.871 & \multirow{5}{*}{2.8777} & \multirow{5}{*}{0.0258} \\
\hline & $30-39$ & 2.458 & 1.179 & & \\
\hline & $40-49$ & 2.250 & 1.125 & & \\
\hline & $50-59$ & 2.429 & 1.469 & & \\
\hline & $60+$ & 1.619 & 1.024 & & \\
\hline \multirow{5}{*}{$\begin{array}{l}\text { During elections I vote for a person, not } \\
\text { for the party }\end{array}$} & $20-29$ & 3.675 & 1.047 & \multirow{5}{*}{0.6581} & \multirow{5}{*}{0.6224} \\
\hline & $30-39$ & 3.333 & 1.239 & & \\
\hline & $40-49$ & 3.188 & 1.223 & & \\
\hline & $50-59$ & 3.333 & 1.197 & & \\
\hline & $60+$ & 3.333 & 1.528 & & \\
\hline & $20-29$ & 3.500 & 1.198 & & \\
\hline 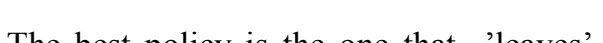 & $30-39$ & 3.542 & 1.285 & & \\
\hline The best policy is the one that 'leaves' & $40-49$ & 3.875 & 1.088 & 7.1007 & 0.0000 \\
\hline & $50-59$ & 4.667 & 0.730 & & \\
\hline & $60+$ & 4.667 & 0.913 & & \\
\hline & $20-29$ & 3.650 & 1.051 & & \\
\hline & $30-39$ & 3.333 & 1.007 & & \\
\hline If I were the politician I would know & $40-49$ & 3.812 & 0.911 & 1.2329 & 0.3008 \\
\hline & $50-59$ & 3.952 & 0.921 & & \\
\hline & $60+$ & 3.810 & 1.123 & & \\
\hline & $20-29$ & 3.350 & 1.189 & & \\
\hline Very often the members of the same & $30-39$ & 2.833 & 1.090 & & \\
\hline family are the members of different & $40-49$ & 2.812 & 1.109 & 4.3744 & 0.0025 \\
\hline parties & $50-59$ & 3.048 & 1.499 & & \\
\hline & $60+$ & 2.048 & 0.865 & & \\
\hline
\end{tabular}

Stance seven: 'At the elections I vote for person, not for the party'. The will of voters depends from the voting system and may have the influence on selection of candidates (Orlović, 2012). Opened lists depend from personal support of voters, so connections with the party are weaker and it is also the party discipline. Closed lists lead more toward the candidate's dependence from the party (Gallagher, 2008). This stance shows the importance of choice of nominated persons 
in comparison to the program and policy of certain party. The participants are indecisive and mutually do not agree about this question $(\mathrm{M}=3.43, \sigma=1.22)$ (Figure 2). It might mean that they are voting for the party, but they do not exclude the possibility that their decision could be formed under the influence of person's presence who was exposed in the 'public life' by his or her acceptable attitudes concerning the policy or something else. Very often have been engaged the persons all over the world for different political campaigns (Frizzell, 2011; Jenkins \& Shresthova, 2012; Huliaras \& Tzifakis, 2012). The values of descriptive statistics have shown that women agreed with this stance, persons who were not politically active, young generation of age 20-29 and farmers. This fact shows that such categories of inhabitants 'critical mass' are those who are changing the relations among the powers in the policy.

Table 5 One-factor analysis of differences between the inhabitants of rural settlments of Vojvodina based on their activity (M-average value, $\sigma$-standard deviation, for $\mathrm{F}(5,116)$, critic values according to Snedecor \& Cochran table (1980), $\mathrm{p}<0.01 ; \mathrm{F} \geq 3.47 ; \mathrm{p}<0.05 ; \mathrm{F} \geq 2.44$ ), Source: Survey research

\begin{tabular}{|c|c|c|c|c|c|}
\hline Stances & Activity & M & $\sigma$ & $\mathrm{F}$ & $\mathrm{p}$ \\
\hline \multirow{6}{*}{$\begin{array}{l}\text { I regularly follow 'the political } \\
\text { life' in Serbia }\end{array}$} & Employed & 3.195 & 1.308 & \multirow{6}{*}{1.9108} & \multirow{6}{*}{0.0977} \\
\hline & Farmer, but employed & 2.571 & 0.976 & & \\
\hline & Farmer & 3.091 & 1.109 & & \\
\hline & Retired & 3.818 & 0.982 & & \\
\hline & Unemployed & 2.944 & 1.305 & & \\
\hline & Other & 2.609 & 1.118 & & \\
\hline \multirow{5}{*}{$\begin{array}{l}\text { I know who the Minister of } \\
\text { Agriculture is }\end{array}$} & Employed & 3.463 & 1.120 & \multirow{6}{*}{0.5595} & \multirow{6}{*}{0.7308} \\
\hline & Farmer, but employed & 3.286 & 1.254 & & \\
\hline & Farmer & 3.591 & 1.098 & & \\
\hline & Retired & 3.364 & 0.924 & & \\
\hline & Unemployed & 3.167 & 1.150 & & \\
\hline \multirow{6}{*}{$\begin{array}{l}\text { In the countryside are 'felt' } \\
\text { changes in the government }\end{array}$} & Other & 3.130 & 1.180 & & \\
\hline & Employed & 2.854 & 1.256 & \multirow{6}{*}{1.8164} & \multirow{6}{*}{0.1150} \\
\hline & Farmer, but employed & 1.714 & 1.113 & & \\
\hline & Farmer & 2.273 & 1.386 & & \\
\hline & Retired & 2.545 & 1.214 & & \\
\hline & Unemployed & 2.778 & 1.060 & & \\
\hline \multirow{7}{*}{ Women should be in the policy } & Other & 2.174 & 1.337 & & \\
\hline & Employed & 3.756 & 1.044 & \multirow{6}{*}{0.5728} & \multirow{6}{*}{0.7207} \\
\hline & Farmer, but employed & 4.000 & 1.155 & & \\
\hline & Farmer & 3.364 & 1.177 & & \\
\hline & Retired & 3.545 & 1.128 & & \\
\hline & Unemployed & 3.722 & 1.179 & & \\
\hline & Other & 3.522 & 1.201 & & \\
\hline \multirow{6}{*}{$\begin{array}{l}\text { Politicians are the most present in } \\
\text { the countryside during election } \\
\text { campaign }\end{array}$} & Employed & 3.878 & 1.288 & \multirow{6}{*}{1.1942} & \multirow{6}{*}{0.3164} \\
\hline & Farmer, but employed & 3.714 & 1.890 & & \\
\hline & Farmer & 4.227 & 1.066 & & \\
\hline & Retired & 3.182 & 1.471 & & \\
\hline & Unemployed & 4.000 & 1.029 & & \\
\hline & Other & 3.609 & 1.373 & & \\
\hline \multirow{5}{*}{$\begin{array}{l}\text { Current local politicians are also } \\
\text { good masters }\end{array}$} & Employed & 2.390 & 1.070 & \multirow{6}{*}{0.8640} & \multirow{6}{*}{0.5076} \\
\hline & Farmer, but employed & 2.143 & 1.215 & & \\
\hline & Farmer & 2.409 & 1.333 & & \\
\hline & Retired & 2.091 & 1.221 & & \\
\hline & Unemployed & 2.667 & 1.237 & & \\
\hline \multirow{7}{*}{$\begin{array}{l}\text { During elections I vote for a } \\
\text { person, not for the party }\end{array}$} & Other & 2.000 & 0.953 & & \\
\hline & Employed & 3.634 & 1.199 & \multirow{6}{*}{0.9623} & \multirow{6}{*}{0.4440} \\
\hline & Farmer, but employed & 3.714 & 0.756 & & \\
\hline & Farmer & 3.545 & 1.143 & & \\
\hline & Retired & 2.909 & 1.578 & & \\
\hline & Unemployed & 3.167 & 1.295 & & \\
\hline & Other & 3.304 & 1.185 & & \\
\hline \multirow{3}{*}{$\begin{array}{l}\text { The best policy is the one that } \\
\text { 'leaves' the most in the villager's } \\
\text { pocket }\end{array}$} & Employed & 3.659 & 1.196 & \multirow{3}{*}{2.9262} & \\
\hline & Farmer, but employed & 4.429 & 0.787 & & 0.0159 \\
\hline & Farmer & 4.545 & 0.912 & & \\
\hline
\end{tabular}




\begin{tabular}{|c|c|c|c|c|c|}
\hline \multirow{9}{*}{$\begin{array}{l}\text { If I were the politician I would } \\
\text { know what should be changed }\end{array}$} & Retired & 4.455 & 1.214 & \multirow{9}{*}{1.6863} & \multirow{7}{*}{0.1433} \\
\hline & Unemployed & 3.500 & 1.425 & & \\
\hline & Other & 3.913 & 1.083 & & \\
\hline & Employed & 3.780 & 1.037 & & \\
\hline & Farmer, but employed & 4.286 & 0.488 & & \\
\hline & Farmer & 3.864 & 1.125 & & \\
\hline & Retired & 3.818 & 0.982 & & \\
\hline & Unemployed & 3.500 & 1.098 & & \multirow{8}{*}{0.0525} \\
\hline & Other & 3.261 & 0.864 & & \\
\hline \multirow{6}{*}{$\begin{array}{l}\text { Very often the members of the } \\
\text { same family are the members of } \\
\text { different parties }\end{array}$} & Employed & 2.902 & 1.200 & \multirow{6}{*}{2.2651} & \\
\hline & Farmer, but employed & 3.143 & 1.574 & & \\
\hline & Farmer & 3.364 & 1.255 & & \\
\hline & Retired & 1.909 & 0.831 & & \\
\hline & Unemployed & 3.000 & 0.970 & & \\
\hline & Other & 2.783 & 1.347 & & \\
\hline
\end{tabular}

Stance eight: 'The best policy is the one which 'leaves' the most in the pocket of the peasants'. This stance shows how much the participants are ready for changes. Is it still the best policy the one by which could be realized the biggest profit? How many are those who observe the things from the 'higher level'? Should someone works with less profit for the 'higher aims', or sustainable development? In comparison to the other stances, the most participants agreed with the stance $(\mathrm{M}=3.96, \sigma=1.20)$. It might be said that for them the earnings is the measure of good policy. About such phenomenon were writing Bromley (1989); Grant (2012); Akram-Lodhi \& Kay (2012) and others. It should have in mind that the agriculture in Serbia as well as in Vojvodina has many problems and it is in crisis for a long time. The experts pointed out some of them, such as: nonexistence of clear strategy for agriculture development, villages and rural development as a new developing philosophy in EU; there is no clear and kept model for financing of agriculture from which the farmers could see for longer period how much money and how long the country intends to be separated from the Budget; the needs for regional maintained programs in agriculture and production for known customer and etc. (Pejanović, 2011). This explains the fact that all categories of participants agreed about this question. Politically active persons have shown high level of mutual agreement $(\sigma=0.97)$ which pointed out that their presence in policy is more economically than ideologically motivated. According to age criteria, one-factory analysis of ANOVA variance, at the importance level $\mathrm{p}<0.01 ; \mathrm{F} \geq 3.47$ pointed out significant differences among the participants (Table 4). According to descriptive statistics the young ones (20-29 and 30-39) agreed with such stance and the oldest participants (50-59 and 60+) fully agreed with stance and have achieved a high degree of mutual agreement. Post-hoc Tukey HSD test, at importance level of $p<0.01$ confirmed that statistically important differences were realized between declarations of younger inhabitants (20-29 and 30-39) and the oldest inhabitants (50-59 and 60+) (Table 6). According to activity criteria, one-factory analysis ANOVA variance, at importance level $\mathrm{p}<0.05 ; \mathrm{F} \geq 2.44$ has pointed out the statistically moderate differences among the partipants. Post-hoc Tukey HSD, has confirmed differences between the farmers and unemployed, on significance level $\mathrm{p}<0.05$ (Table 7). According to descriptive statistics, the farmers fully agree with this stance $(\mathrm{M}=4.55)$ while the unemployed hardly agreed with it $(\mathrm{M}=3.50)$.

Stance nine: 'If I were the politician, I know exactly what should be changed'. The participants declared as 'I agree' but they have shown the highest level of mutual agreement for chosen reply $(\mathrm{M}=3.69 ; \sigma=1.02)$ in comparison with other hypotheses. T-test has established statistically moderate significant differences between genders $\mathrm{p}<0.05$, according which men were surer about their answer. Statistical differences between politically active persons and those who were not, $T$-test identified on the level of $p<0.01$. It was expected, because those who were politically active had clear vision about their political aims and they are mutually agreeable $(\sigma=0.88)$ (Table 3). One-factory analysis of ANOVA variance, at importance level $p<0.01 ; \mathrm{F} \geq 3.47$, has not established statistically important differences among the participants. But descriptive statistic has shown that the category of participants '30-39 years old' per age criteria and category 'others' per criteria of activity were not sure that they knew exactly what should be changed if they 
were in the place of influential politician. The other participants declared that they knew exactly what should be changed. There are opposite opinions about it how appropriate and in what way feasible to involve people into the process of deciding (Ćeranić, 2005; Altman, 2011; Štrek, 2012; Gačević, 2012), but there is a positive attitude about it among them.

Table 6 Post-hoc Tukey HSD test for stances where the one-factor analysis ANOVA established the differences in opinions of the participants in different age groups (MSE - mean square error, q-relevant critical value of the studentized range statistic, $n$-number of scores used in calculating the group means of interest, according to the Tukey table (2014), $p>0.01$, sign not important), Source: Survey research and own calculations

\begin{tabular}{|c|c|c|c|c|c|}
\hline \multirow{3}{*}{$\begin{array}{l}\text { Tukey } \\
\text { HSD }\end{array}$} & \multicolumn{2}{|l|}{$H S D$} & \multirow{3}{*}{$\begin{array}{l}\text { I regularly follow 'the } \\
\text { political life' in Serbia }\end{array}$} & \multirow{4}{*}{$\begin{array}{l}\text { The best policy is } \\
\text { the one that 'leaves' } \\
\text { the most in the } \\
\text { villager's pocket } \\
4.71 \text { if } \mathrm{p}<0.01\end{array}$} & \multirow{3}{*}{$\begin{array}{l}\text { Very often the members of } \\
\text { the same family are the } \\
\text { members of different parties }\end{array}$} \\
\hline & & $M S E$ & & & \\
\hline & $=q *$ & $\bar{n}$ & & & \\
\hline \multicolumn{2}{|c|}{ q (from the table) } & & & & \\
\hline \multirow{2}{*}{\multicolumn{2}{|c|}{$\begin{array}{l}\text { MSE } \\
N\end{array}$}} & & 1.320 & 1.188 & 1.374 \\
\hline & & & 24.4 & & \\
\hline \multicolumn{2}{|l|}{ HSD } & & 1.0955 & 1.0393 & 1.1177 \\
\hline & & & Differences in mean values & & \\
\hline $20-29$ & $30-39$ & & 0.192 & -0.042 & 0.517 \\
\hline $20-29$ & $40-49$ & & -0.037 & -0.375 & 0.538 \\
\hline $20-29$ & $50-59$ & & -0.844 & -1.167 & 0.302 \\
\hline $20-29$ & $60+$ & & -0.939 & -1.167 & 1.302 \\
\hline $30-39$ & $40-49$ & & -0.229 & -0.333 & 0.021 \\
\hline $30-39$ & $50-59$ & & -1.036 & -1.125 & -0.215 \\
\hline $30-39$ & $60+$ & & -1.131 & -1.125 & 0.785 \\
\hline $40-49$ & $50-59$ & & -0.807 & -0.792 & -0.236 \\
\hline $40-49$ & $60+$ & & -0.902 & -0.792 & 0.764 \\
\hline $50-59$ & $60+$ & & -0.095 & 0.000 & 1.000 \\
\hline
\end{tabular}

Stance ten: 'The members of the same family are very often the members of different parties'. Very often may be seen in literature the influence by family to the characteristics of political perception (Fitzgerald, 2011; Becker, 2013; Chhibber, 2013). Among the inhabitants of Pannonia villages was talked about political pluralism within the family for self-interest, i.e. fulfillment of own interests. Indecisively participants and their mutual disagreement $(\mathrm{M}=2.90$; $\sigma=1.24$ ) show how much the participants are not sure about this stance. Rare one was those who talked in public about their political orientation and they were not politically active. If the participants have agreed about this stance it might mean that, for example, the generation gap influenced on different political attitudes within one family, but the members of one family are also strategically divided by mutual consent per different parties in order to be 'close to the power' and use its privilege. By T-test has not been separated any category of participants, but statistically were important differences between the age categories and identified one-factory analysis of ANOVA variance at the importance level $\mathrm{p}<0.01 ; \mathrm{F} \geq 3.47$ (Table 4). Post-hoc Tukey HSD test, at importance level $\mathrm{p}<0.01$ established that the most differences was among the opinions of the youngest (20-29) and the oldest $(60+)$ participants (Table 6). Namely, only the oldest participants do not agree with this stance and mutually agreed about it $(\mathrm{M}=2.05, \sigma=0.87)$. According to the category for activity, descriptive statistic separated pensioners, who 'do not agree' because this confirmed mentioned results as their age were above 60 years. 
Table 7 Post-hoc Tukey HSD test for stance where the one-factor analysis ANOVA established differences in opinions of participants of different activities (MSE - mean square error, q-relevant critical value of the studentized range statistic, $n$-number of scores used in calculating the group means of interest, according to the Tukey table (2014), p>0.05, sign not important), Source: Survey research and own calculations

\begin{tabular}{lll}
\hline Tukey HSD & \multicolumn{1}{c}{$H S D=q * \sqrt{\frac{M S E}{n}} \quad \begin{array}{l}\text { The best policy is the one that 'leaves' the } \\
\text { most in the villager's pocket }\end{array}$} \\
q (from the table) & $\begin{array}{l}3.92 \mathrm{p}<0.05 \\
\text { MSE }\end{array}$ & 1.323 \\
$\mathrm{~N}$ & & 20.333 \\
HSD & & 0.9999 \\
\hline & & Differences in mean values \\
Employed & Farmer, but employed & 0.770 \\
Employed & Farmer & 0.886 \\
Employed & Retired & 0.796 \\
Employed & Unemployed & -0.159 \\
Employed & Other & 0.254 \\
Farmer, but employed & Farmer & 0.116 \\
Farmer, but employed & Retired & 0.026 \\
Farmer, but employed & Unemployed & -0.929 \\
Farmer, but employed & Other & -0.516 \\
Farmer & Retired & -0.090 \\
Farmer & Unemployed & $-\mathbf{1 . 0 4 5}$ \\
Farmer & Other & -0.632 \\
Retired & Unemployed & -0.955 \\
Retired & Other & -0.542 \\
Unemployed & Other & 0.413 \\
\hline
\end{tabular}

\section{CONCLUSION}

Exactly 122 participants from the area of Vojvodina, North Serbia evaluated the stances formed on the basis of the opinion by smaller number of politically inactive farmers. They agreed the most about stance that 'The best policy is the one that 'leaves' the most in the villager's pocket'. Obviously, economic interests are more important than ideology. They did not agree with stance that 'Current local politicians are also good masters'. Some population of countryside found themselves in policy, not in farming. T-test identified disagreement among different gender concerning regular following of political life in Serbia and concerning the question if women should be involved into policy. According to descriptive statistic men regularly follow political life while the women participants believe that women should deal with policy. Among women exists gender solidarity. T-test has established a disagreement of the participants who were engaged in the policy in relation to those who were not. Politically engaged participants agreed that they regularly followed the political life in Serbia, they confirmed that the politicians are the most present in the village during vote campaign and they exactly know what should be changed if they were in the sphere of influence.

One-factor analysis of ANOVA variance, at importance value $\mathrm{p}<0.01 ; \mathrm{F} \geq 3.47$, has established differences between the participants of different age with stance 'I regularly follow 'the political life' in Serbia', 'The best policy is the one that 'leaves' the most in the villager's pocket' and 'Very often the members of the same family are the members of different parties'. One-factor analysis of ANOVA variance, at importance value $\mathrm{p}<0.05 ; \mathrm{F} \geq 2.44$, has established differences between the participants of different activities were noticed with stance 'The best policy is the one that 'leaves' the most in the villager's pocket'.

The presence of the participants of different activities in random sample illustrates that the countryside is not a place where only the farmers live. Most of rural settlements of Vojvodina are quite urbanized and younger inhabitants use all available technical possibilities for informing. However, from all inhabitants in rural settlements, the farmers follow the political life the most and 
they are well informed about it. The policy is often a theme of their communication and they have their attitude.

The countryside inhabitants think that the presence of politicians in village is desirable even out of the vote campaign'. If they work for the people, then they should do what is needed, but not what they are thinking that should be done'. This article represents the contribution to promote the quality of relations among voters and those who they voted for in the function of realizing the mutual aims. Conducting of constructive ideas deriving from the countryside may increase the visibility of the political activity efficiency and positively influenced on its rating.

\section{ACKNOWLEDGMENT}

This paper is part of the project No. 114-451-2644/2014-02 funded by the Provincial Secretariat for Science and Technological Development of the Vojvodina Province, Serbia. The authors are grateful to the reviewers, whose comments and criticisms have ensured the quality of the paper.

\section{References}

[1] Akram-Lodhi, A., Haroon; Kay, C., (ed.), Peasants and Globalization: Political Economy, Agrarian Transformation and Development. Routledge, 2012.

[2] Altman, D., Direct democracy worldwide. New York: Cambridge University Press, 2011.

[3] Anojčić, I., '(Un)certain voice' (In Serbian), Politika, 9 January 2008, p. 5.

[4] Bagozzi, P., R., 'Evaluating Structural Equation Models with Unobservable Variables and Measurement Error: A Comment', 1981, Journal of Marketing Research, p. 18: 380.

[5] Bagozzi, P., R., Yi, Y., 'Specification, evaluation, and interpretation of structural equation models', 2012, Journal of the Academy of Marketing Science 40.1: 8-34.

[6] Bartlett, E., J., Kotrlik, W., J., Chadwick, C., H., 'Organizational Research: Determining Appropriate Sample Size in Survey Research', 2001, Information Technology, Learning, and Performance Journal. 19: 1, p. 43-50.

[7] Becker, E., T., 'Nepotism and the Commitment of Relevant Parties', 2013, Nepotism in Organizations: 129.

[8] Blunden, J., Curry, N., A future for our countryside. Basil Blackwell Ltd, 1988.

[9] Bratton, M., 'Non-governmental Organizations in Africa: Can They Influence Public Policy?' 1990, Development and Change 21:1, p. 87-118.

[10] Bromley, W., D., Economic interests and institutions: The conceptual foundations of public policy. Oxford: Basil Blackwell, 1989.

[11] Ćeranić, J., 'Democratic life in the European Union' (In Serbian), 2005, Revija za evropsko pravo, 7:1, p. 5-21.

[12] Chhibber, P., 'Dynastic parties Organization, Finance and Impact.' 2013, Party Politics 19:2, p. 277-295.

[13] Čičkarić, L., 'Political identity from a gender perspective' (In Serbian), 2005, Genero, 06-07, p. 9-27.

[14] Čičkarić, L., 'Youth and new politics: Global changes: Local lives', 2007, Sociološki pregled, 41:2, p. 251-264.

[15] Fitzgerald, J., 'Family dynamics and Swiss parties on the rise: Exploring party support in a changing electoral context', 2011, Journal of Politics 73:3, p. 783-796. 
[16] Đinđić, Z., Sećanje, 'In the global economy of the 21 st century, there are only successful and unsuccessful' (In Serbian), 2013, Bankarstvo Magazine 1, p. 6-11.

[17] Dramstad, E., W., Fjellstad, J., W., Strand, G., H., Mathiesen, H., F., Engan, G., Stokland, N., J., Development and implementation of the Norwegian monitoring programme for agricultural landscapes', 2002, Journal of Environmental Management, 64 (1), p. 49-63.

[18] Dwyer, J., 'UK Land use futures: Policy influence and challenges for the coming decades', 2011, Land use policy 28:4, p. 674-683.

[19] Frizzell, C., 'Public opinion and foreign policy: The effects of celebrity endorsements', 2011, The Social Science Journal, 48:2, p. 314-323.

[20] Gaćeša, L., N., Agrarian Reform and Colonization in the Banat: 1919-1941' (In Serbian), Institut za izučavanje istorije Vojvodine; Matica srpska - Odeljenje za društvene nauke, 2, 1972.

[21] Gaćeša, L., N., Agrarian Reform and Colonization in the Srem: 1919-1941. (In Serbian), Institut za izučavanje istorije Vojvodine, 1975.

[22] Gačević, M., Alter globalist movement and revolution? Crisis, responses, left, Contributions to a critical discourse (In Serbian), Roza Luxemburg Stiftung, Regionalna kancelarija za jugoistočnu Evropu, Beograd 2012.

[23] Gallagher, M., Conclusion, in: The Politics of Electoral Systems, (ed.) Gallagher Michael Gallagher and Mitchell Paul, Oxford University Press, 2008.

[24] Gardiner, F., (ed.), Sex equality policy in Western Europe, Routledge, 2013.

[25] Grant, W., 'Economic patriotism in European agriculture', 2012, Journal of European Public Policy, 19:3, p. 420-434.

[26] Haerpfer, C., Wallace, C., Spannring, R., Young people and politics in eastern and western Europe, Inst. für Höhere Studien (IHS), 2002.

[27] Huliaras, A., Tzifakis, N., 'The fallacy of the autonomous celebrity activist in international politics: George Clooney and Mia Farrow in Darfur', 2012, Cambridge Review of International Affairs, 25:3, p. 417-431.

[28] Iacobucci, D., 'Structural equation modeling: fit indices, sample size, and advanced topics', 2010, Journal of Consumer Psychology, 20, p. 90-98.

[29] Jamieson, D., 'Ethics, public policy, and global warming', 2010, Climate ethics, essential readings, p. 77-86.

[30] Janjetović, Z., 'National minorities in Yugoslavia 1918-1941', 2012, Review of Croatian History 1, p.61-75.

[31] Jenkins, H., Shresthova, S., 'Up, up, and away! The power and potential of fan activism', 2012, Transformative Works and Cultures, 10.

[32] Kamenov, Ž., Huić, A., Ajduković, D., Jelić, M., Jugović, I., Baranović, B., Leinert-Novosel, S., Svijest o rodnoj (ne) ravnopravnosti u RH i iskustva rodne diskriminacije u obitelji, obrazovanju, poslu i politici (In Croatian). In 18. godišnja konferencija psihologaKroskulturalna psihologija. 2010.

[33] Krook, M., L., Norris, P., 'Beyond Quotas: Strategies to Promote Gender Equality in Elected Office', 2014, Political Studies, 62:1, p. 2-20.

[34] Ladd, McDonald J., Lenz, S., G., 'Does Anxiety Improve Voters' Decision Making?' 2011, Political Psychology 32: 2, p. 347-361. 
[35] Ljubojević, R., 'Land property relations in Yugoslavia during dictatorship of King Aleksandar', 2011, Megatrend revija 8:2, p. 355-378.

[36] Lukić, T., Penjišević, I., Đerčan, B., Đurđev, B., Bubalo Živković, M., Armenski, T., 'Politics in the Balkan countryside: case study in Serbia', 2014, Eastern European Countryside, 20, p. 99-124.

[37] Map 1, The Province of Vojvodina, blank map, http://upload.wikimedia.org/wikipedia/commons/thumb/8/8b/Serbia_Vojvodina_location_ma p.svg/250px-Serbia_Vojvodina_location_map.svg.png, accessed $7^{\text {th }} \overline{\text { July }} 2014$.

[38] O'Brien, J., K., 'Implementing political reform in China's villages', 1994, The Australian Journal of Chinese Affairs, 32, p. 33-59.

[39] Orlović, S., Re-design of political institutions, in: Vukašin Pavlović (ur.), The quality of political institutions (In Serbian), Fakultet političkih nauka - Centar za demokratiju, Beograd, p. 89, 2010.

[40] Orlović, S., 'The political consequences of electoral system in Serbia'(In Serbian), 2012, Politički život, 4, p. 19-36.

[41] Pearson, E., Sharpe, H., Herman, O., (ed.), Biometrika Tables for Statisticians, 1, p. 146, third edition, 1966.

[42] Pejanović, R., 'On agricultural crisis', 2011, Letopis naučnih radova Poljoprivrednog fakulteta $35: 1$, p. 5-16.

[43] Pejanović, V., R., Tica, L., N., 'Poljoprivreda i reforme privrede (In Serbian)' 2001, Ekonomist, 54:3, p. 159-169.

[44] Ramač, J., 'From the Past of Kisac, till 1773rd year' (In Serbian), 2012, Годишњак Филозофског факултета у Новом Саду, 37-I, p. 427-441.

[45] Ramet, P., S., Serbia since 1989: Politics and Society under Milosevic and After, University of Washington Press, 2005.

[46] Raosoft, Simple size calculator, http://www.raosoft.com/samplesize.html, accessed May $15^{\text {th }}$, 2014.

[47] Robson, A., W., 'Government Publicity', 1940, The Political Quarterly, 11:3, p. 219-231.

[48] RZS (2014): Population, age and gender, Census 2011, Database, Statistical Office of The Republic of Serbia at http://webrzs.stat.gov.rs/WebSite/public/ReportView.aspx, accessed May $04^{\text {th }}, 2014$.

[49] Scott, J., A., Shorten, J., Owen, R., Owen, I., 'What kind of countryside do the public want:

[50] community visions from Wales UK?', 2011, GeoJournal 76:4, p. 417-436.

[51] Shortall, S., A Living Countryside? The Politics of Sustainable Development in Rural Ireland. Ashgate Publishing, Ltd, 2012.

[52] Snedecor, G., W., Cochran, W., G., Statistical Methods. Ames, Iowa: Iowa State University Press, 1980.

[53] Spasić, I., Petrović, T., 'Variants of 'Third Serbia', 2012, Filozofija i društvo, 23:3, p. 23-44.

[54] Štrek, V., The crisis of democratic capital, Crisis, responses, left, Contributions to a critical discourse (In Serbian), Roza Luxemburg Stiftung, Regionalna kancelarija za jugoistočnu Evropu, Beograd, 2012.

[55] Tukey table, Q Table for Tukey`s HSD, http://www.stat.duke.edu/courses/Spring98/sta110c/qtable.html, accessed July $4^{\text {th }}, 2014$. 
[56] Viđen, S., 'Policy and women' (In Bosnian), 2010, Godišnjak Fakulteta Političkih Nauka Sarajevo, 2010.

[57] Vokić Pološki, N., Bulat, I., What women leaders entered politics - psychological and occupational characteristics, leadership style, interests and perspectives? (In Croatian), Faculty of Economics and Business, University of Zagreb, 2013.

[58] Wallace, C., Introduction: youth and politics, 2003, Journal of youth studies, 6:3, p. 243-245.

[59] Winter, M., Rural politics: policies for agriculture, forestry and the environment. Routledge, 2013.

[60] Zentai, L., Relief map of Pannonian plain, 1996, http://lazarus.elte.hu/hun/summer.jpg, accessed $5^{\text {th }}$ July 2014. 